\title{
Collective Action Typologies and Reforestation in Indigenous Community of Biak-Papua
}

\author{
Henry Silka Innah ${ }^{* 1}$, Didik Suharjito ${ }^{2}$, Arya Hadi Dharmawan ${ }^{3}$, Dudung Darusman ${ }^{2}$ \\ ${ }^{1}$ Graduate School of Bogor Agricultural University, Dramaga Main Road, Campus IPB Dramaga, Bogor 16680 \\ ${ }^{2}$ Department of Forest Management, Faculty of Forestry, Bogor Agricultural University, \\ Academic Ring Road, Campus IPB Dramaga, PO Box 168, Bogor 16680, Indonesia \\ ${ }^{3}$ Department of Communication and Community Development Sciences, Faculty of Human Ecology, \\ Bogor Agricultural University, Kamper Road, Campus IPB Dramaga, \\ PO Box 168, Bogor 16680, Indonesia
}

Received April 2, 2012/Accepted January 30, 2013

\begin{abstract}
While there are issues in deforestation with interesting reports on reforestation in Indonesia's forest policy, the situation in Papua remains understudied. This paper builds on the themes of collective action and reforestation from indigenous people of Papua. Collective action can be understood from various perspectives and one of them can be studied within Gamson's socio-psychology framework from social movement theories. The results showed that: collective action in indigenous people of Biak-Papua was connected to their collective identity, solidarity, consciousness, and was facilitated by micromobilization. There were 4 typologies of collective action for reforestation in Biak: (1) collective action with initiative of collectivity in the group supported by external forces, (2) collective action driven by village leaders that have the authority from the government, (3) collective action driven by informal leaders (genealogical/kinship based traditional leaders), and (4) collective action driven by an outsider that has obtained legitimacy of customary, because of marriages. Taking into account its potentials and dynamics, mutually beneficial collective action is believed to be able to support the success of reforestation and forest management in Papua.
\end{abstract}

Keywords: deforestation, identity, solidarity, consciousness

*Correspondenceauthor,email:henry_si@yahoo.com,telp/fax: +62-986-213437/+62-986-213441

\section{Introduction}

Notwithstanding the fact that deforestation has been an issue and interests of various parties, reforestation movement (tree planting movement) has occurred in several regions. This was confirmed through the accomplishment of forest tree planting indicated by the increase of forest coverage. Social and economic experts have proposed explanations on the phenomena of the growth of forest planting/ establishment in the world (Rudel 2009; Rudel et al. 2010). According to Rudel, economists theorize that the current growth of all forms of forest planting is influenced by the scarcity of wood forest product in the world. This phenomenon is explained through forest transition theory (FTT), political decision theory, and human ecology theory. These theories respectively describe the fact of the aggregate of increasing forest area, intervention of government policy to reforestation, and the relationship between human and its environment. On the other hand, Le (2011) suggested that accomplishment of reforestation is supported by the following factors:

1 technical/biophysical,

2 socio-economy,

3 institution, policy, and management, and
4 holding specific characters such as goal, doer, location/access, areal, funding sponsor, project period, and being carried out in public land or private land.

Furthermore, the indicators of reforestation achievement can be evaluated from the extent of surviving plants and the ratio between planted area and the target of planting area. The above mentioned theories have not yet explained in detail how reforestation is influenced by the movement of indigenous community. Indigenous community is the most important component in forest and environmental management, since it is related to a piece of forest and the need of prosperous and peaceful life, and they should be the masters of their own country (Darusman 2002).

In fact, reforestation is a form of collective action (CA) of stakeholders to carry out planting, and can be considered a social movement. In a social movement, organization aspect, social location, and cost and benefit calculation of a movement is important, however its socio-psychology aspect needs to be considered as well. The present research was aimed at evaluating and explaining the form of CA in the frame of reforestation in the land of indigenous community of Papua. 


\section{Methods}

This analysis conceptualizes CA as heterogenic and sustained activities of action practices or cooperative action associated with the comprehension of actor to accomplish reforestation, action initiated by the existing actors, relatively organized and planned, however it can also include even small scale planting, and its existence can be observed and verified into relatively larger aggregate of planting area. On the other hand, reforestation can be signified as activities to accomplish the growth of long-term plantation or forest plantation on the land of indigenous community.

From the perspective of social movement, CA can surely be carried out due to the presence of resources mobilization (resource mobilization theory), or as the result of certain political situation (political opportunity theory). Without disregarding the application of these theories, Gamson (1992) assumed that collective action framing (CAF) as a socio-physiological dimension, acquires a relatively important role in CA.

CAF is associated with conceptual framing. Vicari (2010) referred to the concept of Goffman works in 1974 as a cognitive scheme or the interpretation scheme of an individual concept to the world she/he entered and organized, so that her/his experience has a significance and meaningful. Collective frame is conviction and comprehension oriented to action that inspire and legitimize a social movement activity, and retain certain course of process (Benford \& Snow 2000).

The present research applied the concept of Gamson Frame emphasizing frame components such as collective identity, how injustice discourse is, and which party is the rival in accomplishing collective objective (Vicari 2010). Gamson (1992) considered the importance of comprehension on collective identity, solidarity and consciousness that worked in movement, and the need of facilitating micromobilization component (Hunt \& Benford 2004).

Collective identity (CI) is an association between individual and its tradition system, or how individual emotion is involved in that of another individual in the same group in an effort associated with social change (Ashmore et al. 2004; Eccles 2009). CI even obscures the boundary between individual and collective interest (Gamson 1992). In socio-cultural studies, culture and identity are intimately associated concept. Identity is the medium of culture, and has been always constructed in culture (Roggeband \& Klandermans 2007). Associated with movement, König (2000) affirms that identity is a source, stabilizing element in modern society, objective of achievement, and a requirement for a CA to proceed. CI can be approached through primordial's theory usually used in explaining ethnic identity, language, or religion; structuralism theory that emphasizes the paradigm of collective behavior and Marxism theory; and constructivist theory that emphasizes individual interaction. Eisenstadt and Giesen referred by König (2000), developed 3 ideal types of CI construction, i.e. primordial with egalitarian character and inclined to be impermeable to other individual/collective identity; traditional with hierarchical character and relatively permeable; and universal as an identity that goes beyond the previous types, or can go beyond the frontier of certain ethnic group. Finally, CI was resynthesized by König into 2 types, i.e. primordial and quasi-traditional primordial. When discussing indigenous people, Barth (1969) specifically links ethnic group as an identity of culture, and analyzes how these culture units sustained and what the influencing factors are. The order of certain ethnic culture is determined by sign, symbol or emerging indicators, and retained basic values.

Solidarity considers how the association is between individual and social system, or how individual builds and sustains loyalty and commitment to another party within the same group, in which commitment signified compliance to undertake what has been declared. Social solidarity according to Durkheim can be in the form of mechanical solidarity influenced by lineage affiliation and commonly existed in rural community, and organic solidarity that has been developed due to inter-individual dependence brought about by specialization and classification of labor after industrialization era (Sammut 2011; Sammut \& Gillespie 2011).

Consciousness is association between cognitive elements and culture, or between individual belief about its social world and the system of culture belief as well as its ideology (Gamson 1992). Giddens (1984) introduced the type of consciousness, i.e. unconscious motif, discursive, and practices; meanwhile Schlitz et al. (2010) stated the levels of consciousness into embedded (consciousness occurring without the influence of social factors, biological and culture, or presocial consciousness), self-reflexive (consciousness that experience is conditioned by social world through reflection and social contemplative), engaged (not only realizing the condition of social environment, but starting to mobilize the desire to contribute through action), collaborative (being aware as part of collectivity and starting to work for others in forming social environment through collaborative action), and resonant (understanding the essence of a relation with other party, where experience is interchanged and arisen, filled, and expressed in group, finally stimulating social change).

Existing reforestation is the effect of CAF process or what Snow (2004) names as transformation. The effect in the form of this transformation can come into view when relationship is built between the level of reforestation complexity and agent involved or influenced. The transformation process intimately associated with micromobilization (actor and network). In the present paper, ideological concept was also used to facilitate the illustration of the main frame of society implementing forest management in Biak (Gamson 1992; Oliver \& Johnston 2000). Planting arrangement and technological innovation found in reforestation was used as explanation of the observed field fact.

In this study, qualitative research was set up through the approach of case study. The method of acquiring data applied to support the analysis and discussion of the study included: documentary study, field observation, and indepth interview. Informant was appointed by combining snowball and semi-directive methods, in which the executor 


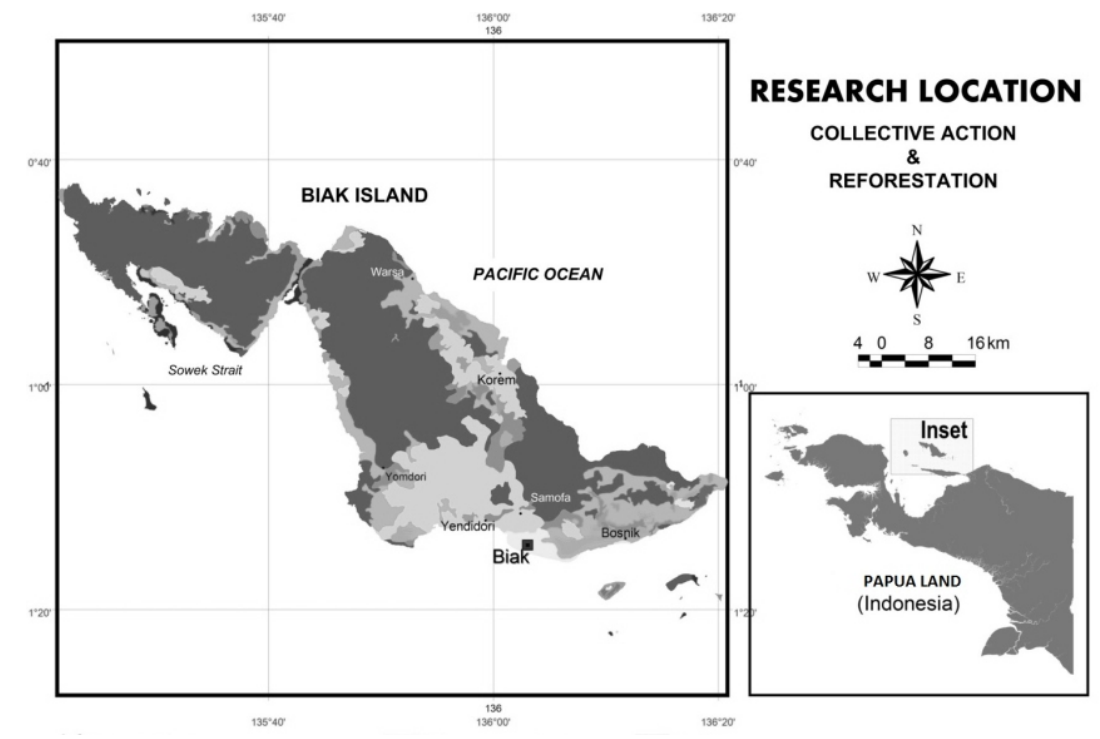

Figure 1 Biak Island as the research locus. Cloud $(\square)$, Primary dry field forest ( $\square$ ), secondary dry field forest ( $\square$ ), Prymary mangrove forest ( $\square)$, secondary mangrove forest $(\square)$, plantation $(\square)$, settlement area $(\square)$.

of reforestation activity/program was the base point and the final target (accomplished target), will be in the informant of community. Nine groups of community spreading out in almost all corners of Biak were the target of information quarrying. Contents and conversation analysis were used in the present research. The locus of research was the Biak Island of Papua (Figure 1).

\section{Results and Discussion}

Collective action in Biak society Ethnic group of Biak develops and settles in the island of Numfor, Biak, Supiori, and several small islands in the area of Cendrawasih GulfPapua, administratively residing in the regency of Biak Numfor and Supiori, the Province of Papua. At the beginning of this research, several terminologies with collectivity idea of Biak language were obtained. Informants pronounce it as babekayam. Babekayam or collectivity term has the same meaning as that of kobeoser or babeoser. Indigenous personage of Biak defines babekayam as a collectivity conducted by lineage member or inter-lineage in accomplishing certain intention and activity, and conducted by 2 or more members (fararu kayayan fandu snodi suru masiadi). Collectivity in babekayam mainly appeared in the aspect of identity/dignity establishment, inclusive in the moments of ritual practice. In Biak people there is a philosophy that says mai do fa, fai do ma (you offer then I offer, and vice versa/kindness reciprocity) and that becomes an important element in promoting collectivity of the society. Another philosophy is aya kada (if you are able, so am $\mathrm{I} /$ competition). From positive perspective, in certain cases this philosophy promotes babekayam.

The typology of collective action According to the observation in the field, the 9 already observed communities along with their particular characteristics can be generally described as follow: the principal actors who motivate the communities are various, starting on as indigenous figure in Keret, particular figure in Keret who is legitimately being promoted to be head of kampong by government, ordinary member of Keret, till the outsider who originally comes from Java but has long resided in Biak. They typically have experiences out of Biak. In fact, one of the actors (Wompere Community) has experience abroad (Papua New Guinea) and some others have ever visited other areas out of Biak. Their experiences and knowledge in cultivation of lifelong plants are soon applied in their own communities. The central actors of Rumere community and Wompere community have special knowledge since they have visited other areas outside Biak, particularly in dealing with knowledge about eaglewood (gaharu), either corresponding to morphology or cultivation. Indigenous figure in Kapisa community and in Kafiar community have also experiences from outside of Biak since their status as public employees or just paying a visit to their relatives outside of Biak. Meanwhile the actors in Mananwir who obtain governments legitimate have through assignment by local government to participate in the evaluation study of forestry management outside Biak. These actors in Mananwir come from Rumaropen community, Warnares, Rumpaidus, and Msen. Unlikely actors who later recognized by local inhabitant by marriage take place among Korwa community.

The location of the communities spread out within areas of Biak such as East Biak, West Biak, Warsa, North Biak, and Yendidori. The collective action referred to reforestation can be seen and concentrated in small community of Keret, meanwhile in various community go inter-Keret. Even though the planting of life span plantation has been carried out for long in Biak, but in big scale is still in hand of local collective initiatives and initiatives from outside parts. The existence of cooperative work with outside parts increases during its progress. Meanwhile the variety of lifelong plants consists of Aquilaria filaria, Intsia bijuga, Callophylum sp., Palaquium sp., Phaleria sp., and 
Tectona grandis. In accordance to the above description, there are 4 types of collective action related to reforestation in Biak can explicitly illustrated as:

1 The collective action conducted by members of community supported by outsiders. The reforestation is conducted by leader of transformative collective (T1). This type of leader acts as ordinary innovative person inside the community but not as indigenous leader. Anyway this person has influence leadership that can motivate surrounding people and acts within the forest area in his territory. This type of leadership is mostly openhanded to any innovation and having good relationship with outside part. Almost all of his ideas related to reforestation come from interaction with outside world. This reforestation takes place in the area of their community, limited to the areas of Msen (secondary and stony forest authorized by a keret in the community). Most of the reforestation is supported by local initiatives from an innovator inside the community. The key innovation to carry out the forestation is to protect indeginious land from any claim (in small keret). In this circumstance, the reforestation has limited its operation only within the area of small keret excluded other area of other keret. The reforestation in area of other small keret is under the responsibility of other figure. There won't be any desire from this community to participate in the commercializing the reforestation project. Nevertheless this community knows about any economical worth plants (such as gaharu/eaglewood). The collective action appears in reforestation activity based only by the spirit of Gemeinschaft (solidarity). As for instance of this first type is community of small keret Rumere and Wompere. The type of devotion to the action is merely to respect the figure of innovation. The community is motivated to join the collective action of reforestation because the community understands the benefit of the result of reforestation even it is carried out in communal land.

2 The collective action conducted by person in charge in kampong who gets authority from government (T2). This type of reforestation is conducted by local leader or Mananwir (democratically voted leader and later approved by local authority). This type of leader is one who gets formal authority to apply any policy in his kampong following the local authority. This type of characterization is popular as one who gets assurance and having broad network with outsider as his formal status. This figure has power aggreed by formal authority. Reforestation operation is carried out as a project from top (from central authority to local authority). In such way, lot of reforestation program should wait for guidelines from the top (from central authority). Most of the action of reforestation based on transactional devotion (expecting reward from reforestation project programmed by government). As the example for this second type is reforestation conducted by leader of kampong Sunde (Warnares) and leader of kampong Asarkir, incorporated with former leader of kampong Yenusi (Rumpaidus). The devotion to this second type figure is based on respect to formal figure with formal authorization from government. The community takes part in the collective action of reforestation since they put hope to get reward from thee reforestation project applied in communal land as well as the benefit of the reforestation.

3 The collective action conducted by informal figure (indigenious figure based on genealogy). The figure who conducts the collective action of reforestation is Manseren (T3). This Manseren is respected and trusted as indigenious figure by the local community inside keret. This figure is often received legitimate to lead the community due to family tree. The forestation program conducted by this figure is followed by the community for community's respect to this figure. The reforestation program is conducted merely based on the so called figure's initiatives in order to maintain claim of ownership of the territory or tradition territory belongs to community of big keret's territory consist of small keret. The initiative may come from small keret or Manseren

Table 1 Types of collective action and its description

\begin{tabular}{|c|c|c|c|c|}
\hline Characteristic & Type 1 & Type 2 & Type 3 & Type 4 \\
\hline Leadership & Transformative innovator & Formal authority & Traditional characteristic & Rational \\
\hline $\begin{array}{l}\text { Dedication to } \\
\text { collective action }\end{array}$ & $\begin{array}{l}\text { Collectiveness and } \\
\text { respect to innovation }\end{array}$ & $\begin{array}{l}\text { Formal dedication and } \\
\text { having purpose to get } \\
\text { reward from reforestation } \\
\text { project }\end{array}$ & $\begin{array}{l}\text { Traditional dedication } \\
\text { and motivation to } \\
\text { maintain communal area }\end{array}$ & $\begin{array}{l}\text { Knowledge and } \\
\text { commercial dedication }\end{array}$ \\
\hline $\begin{array}{l}\text { Legitimate of } \\
\text { collective action in } \\
\text { reforestation }\end{array}$ & Indigenous law & Formal law & Indigenous law & $\begin{array}{l}\text { Right security on the } \\
\text { private land }\end{array}$ \\
\hline Agrarian base & $\begin{array}{l}\text { Indigenous communal } \\
\text { area (yaflyafdas) }\end{array}$ & $\begin{array}{l}\text { Indigenous communal } \\
\text { area (yaf/yafdas) }\end{array}$ & $\begin{array}{l}\text { Indigenous communal } \\
\text { area (yaflyafdas) }\end{array}$ & $\begin{array}{l}\text { Private land } \\
\text { (for example yaf/yafdas } \\
\text { and marires) }\end{array}$ \\
\hline
\end{tabular}


(leader of big keret). The relation between big keret and small keret is formed through coordination or encouragement only. The reforestation initiatives which is conducted by each small keret will be consented to. The action will be considered as the autonomy of big keret as this figure motivates the reforestation program in the area of his big keret. The example for this third type is the reforestation conducted by big keret Kafiar and Kapisa. The type of devotion to this third type is based on the respect to indignious leader accepted by whole community. The motivation of community to participate in collective reforestation because the community understand the right of the benefit of reforestation even the action conducted in communal area.

4 The collective action conducted by outsider but legitimated by culture through marriage. The reforestation conducted by an individual who comes into the area of small keret through marriage with local inhabitant (T4). The marriage itself becomes legitimate to the outsider who gets married with the local inhabitant to motivate reforestation. Dedication of community based on the willingness to learn something from the outsider who already has experience in reforestation. Type of dedication to this fourth type is to respect knowledge brought by the figure. Moreover there is still rational motivation so long as the community understands that the price of any trees planted in reforestation action is high enough. The reforestation implemented in already permanent indigenous land and safe such as personal ownership. The resume of tipology $\mathrm{AC}$ in indigenous community in Biak can be seen in Table 1.
Value orientation A person's orientation value is driven by the ideological tendency he adopts (Suharjito 2008). If the orientation value is regarded as the ideological push effect, then of course the concept of ideology (read: environmental ideology) of Biak people-related forest management and reforestation can be traced (Weber 2000; Dharmawan 2007; Suharjito 2008; Ojomo 2011). Ideological differences of various ethics/environment morals elaborated by Suharjito (2008) can be seen from the main components.

The group T1 has a mission of managing the available land to meet the needs of the small group of keret. This group understands that humans cannot be separated from the nature, considering land and forests as the mother, and the land can be utilized in the long term for the survival of keret.

Land management and forest owned by certain keret to meet the needs of keret are the mission of the group T2. Like other groups, this group views the nature forest and its landas something that can not be separated from man, and should be utilized in the long term. Forest and its land are understood as the mother.

Although their understanding that forest and its land are the mother, the group T3 has great respect for certain areas that are considered to have historical value and the value of certain supernatural. These areas must be retained as the emblem and symbol of identity, for instance, the first time Biak people set foot and spread throughout the region of Biak today.

In T4, land is valued as economic goods that need to be utilized optimally. Land owned, despite its limited size, has benefits in the long term, because it can provide a living for

Table 2 Orientation characteristics of ideological values of mama

\begin{tabular}{|c|c|c|}
\hline Characteristics & Sample statements & Ideological trend \\
\hline Main mission & $\begin{array}{l}\text { Forest is valuable and it can support human life in term of oxygen to breathe } \\
\text { and forest products. Trees grew into large timbers before they were cut down } \\
\text { for planting taro and sweet potato. However, nowadays new trees of } 1 \text { or } 2 \mathrm{~m} \\
\text { tall are removed for plantation. Similarly, marires are burned here and there, } \\
\text { resulting in a loss for us. Therefore, the forest should be utilized properly for } \\
\text { our benefits. }\end{array}$ & $\begin{array}{l}\text { Grass root } \\
\text { Environmental } \\
\text { Management (GREM) }\end{array}$ \\
\hline $\begin{array}{l}\text { Man-nature } \\
\text { relationship }\end{array}$ & $\begin{array}{l}\text { Forest is the mama. That is the intrinsic value. Forest is the ki tchen and a place } \\
\text { to search for. "So, basically God created forests everywhere. But once people } \\
\text { live, cultivate and search for food in the areas, they will leave shrubs. When } \\
\text { there seem no big trees, it means it was an ex-garden. Later when we have } \\
\text { seen land like this (pointing to unfertile land/marires), a major concern will } \\
\text { appear, trying to return it to its original condition. }\end{array}$ & Contemporary \\
\hline $\begin{array}{l}\text { Value of nature and } \\
\text { nutural resources }\end{array}$ & $\begin{array}{l}\text { As a community member, first, the forest is for gardening, and second, for } \\
\text { hunting, so it needs to be protected, so that nobody will destroy it. The forest } \\
\text { behind us is in a place for hunting, and generally wildlife refuge in the forest. } \\
\text { So forest protects us and at the same time we can do gardening. }\end{array}$ & GREM \\
\hline $\begin{array}{l}\text { Perspective of time } \\
\text { dimension }\end{array}$ & $\begin{array}{l}\text { Since we were born, we have learned that the earth and everything in it has been } \\
\text { made for people. All generations know that forest is like a barn for living on } \\
\text { earth. }\end{array}$ & GREM \\
\hline
\end{tabular}


keret's children and grandchildren if managed with certain considerations. By using the framework of Weber (2000), the environmental ideology in Biak is the ideology of mama, as described in Table 2 .

\section{Elements of CA related to reforestation}

1 Collective identity, solidarity and consciousness CAF in Biak-Papua society is an important aspect to explain how reforestation activities occurred in the land of indigenous community. Informants enthusiastically reported their opinion on the accomplished reforestation activities (Table 3), that then synthesized as part of CAF component.

2 Lineage network

Redfiled confirmed that a small community is an integrated part of its natural environment where the community exists. Therefore, Koentjaraningrat (1990) considered that a small community is an ecological

Table 3 The component of collective identity, solidarity and consciousness

\begin{tabular}{llll}
\hline Aspect & \multicolumn{1}{c}{ Example of statement } & $\begin{array}{l}\text { Frame } \\
\text { component }\end{array}$ & \multicolumn{1}{c}{ Description } \\
\hline $\begin{array}{l}\text { Collective } \\
\text { identity }\end{array}$ & $\begin{array}{l}\text { "Yes...I understood that well, as forestry program, I } \\
\text { always inform the society. When we defend our } \\
\text { dignity well, certainly we will not be considered as } \\
\text { ordinary people. Basic principle of people is that even } \\
\text { though poor, but the dignity is always defended. The }\end{array}$ & Identity & $\begin{array}{l}\text { Working hard, being honest and standing for } \\
\text { dignity. Compared this to the writing of Kamma } \\
\text { in 1994 giving the impression that the people of }\end{array}$ \\
& $\begin{array}{l}\text { Biak are belligerent and dare to take dangerous } \\
\text { risk, and traveling across islands and the oceans. }\end{array}$
\end{tabular}
words are Biar konaroi nofa, kanggenem, stealing and cheating are two obsessions that the people of Biak cannot possess".

"But they say agarwood, so I planted it as well".

Solidarity "Despite of watching him plant, we had better also plant...or we join him so that we can have a tree like that. The terminology of "KOFUKEN" which means: Kofukno caran sawitker bik dundo nanenya.. yu ker naya .. insa mai do bisa kak furda...muda for muda kak keri norari, thus when succeeded, do ko ka ko, kako succeeded. We are also men.... We all are capable......".

\section{Agency \\ Others, who succeeded, motivate the people of Biak to enjoy the success together.}

\begin{tabular}{|c|c|c|}
\hline $\begin{array}{l}\text { "I put Amber on. He comes here not only to farm here } \\
\text { and to take this land, but he just seeks a living, but how } \\
\text { do we apply the control now? I spare the place and I do } \\
\text { not want to claim even a cent from you sir; however, }\end{array}$ & Agency & $\begin{array}{l}\text { Maintaining plantation while helping others in } \\
\text { need of help; motivating and being willing to } \\
\text { transfer technologies (motive: instrumental, } \\
\text { effective, morality). }\end{array}$ \\
\hline
\end{tabular}
plantation)"

"Lets us work...We are thieves and are beaten and sent to jail. But we work and this good is useful for our family. Let's work, and I will give you this knowledge. You must try to be like me too. Don't let me do it alone. In the future you too will be able to lead us. I am a member too, and there is no eason that we cannot".
Conscious In fact we have extended land there. However ness problems exist....the problems existed when our parent were still alive. They had not bothered, but when our parents ceased, and other folks came in, they claimed they owned the place.
Injustice Tree planting as endeavor to preserve the remaining land from occupation of others' in the other land of keret. 


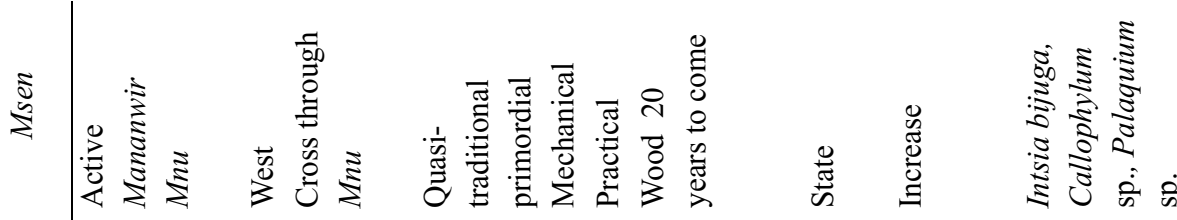

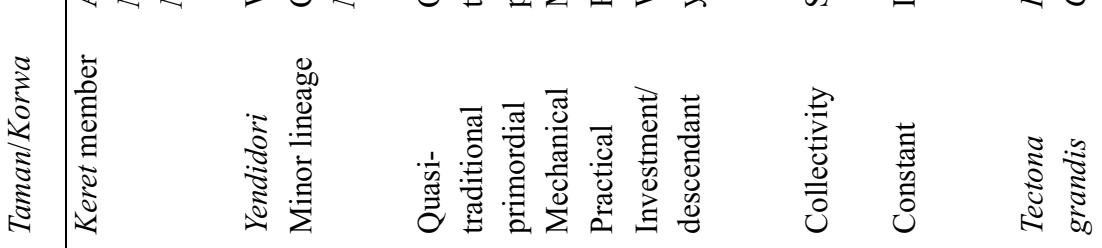

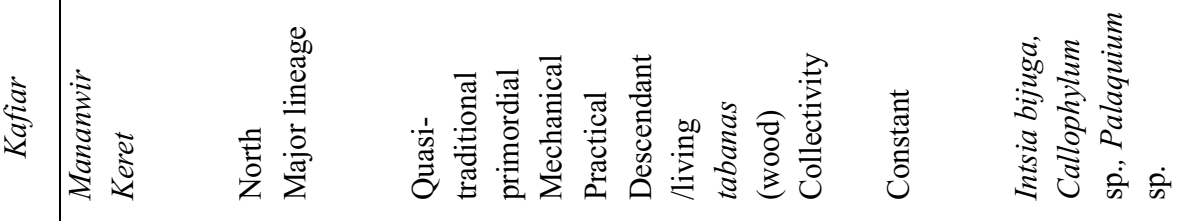

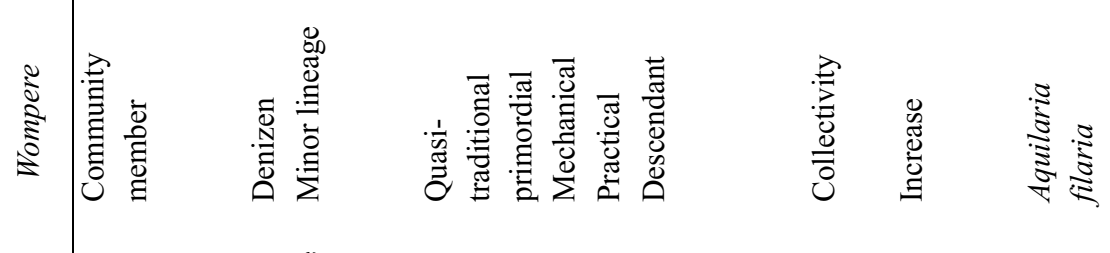

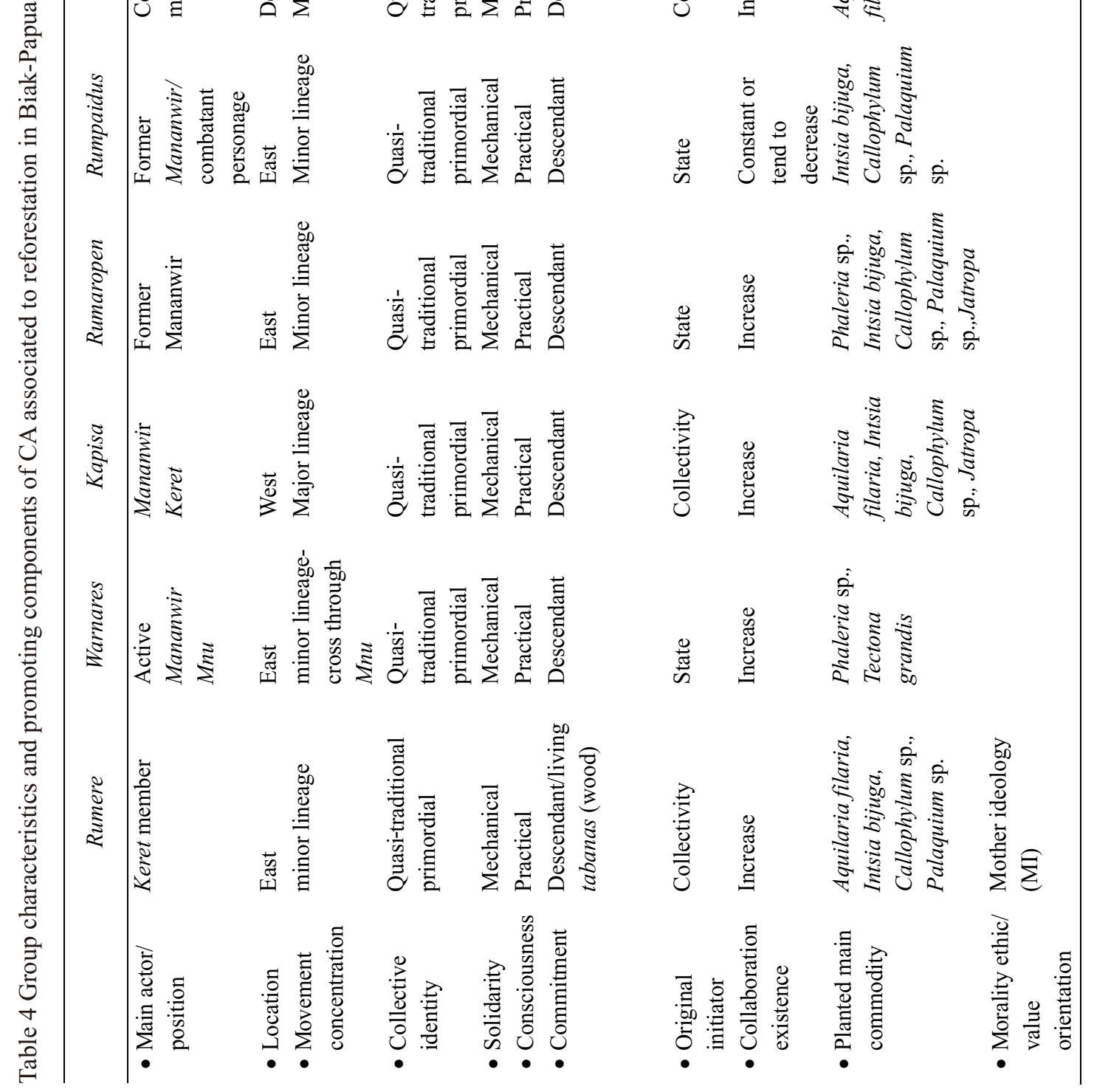


system, in which society and the culture of population, and local environment are 2 main elements in an established reciprocal influence circle. This is why location identity is commonly very strong in the attitude of life of the small community inhabitants as territoriallybased social field.

Reforestation responded through the establishment of kelompok tani hutan $(\mathrm{KTH})$ indicated that almost all group members have the same Fam/keret name (lineage group in Biak). Reforestation activities have undergone in keret, more specifically in Sim (group of close lineage). Grouping based on relatives relationship even facilitate the group initiator or leader in regulating trust, commitment, willingness and reciprocal relationship (Selamat et al. 2010).

In another case, e.g. in the case of reforestation in Asarkir-West Biak, CA can be built inter-тпи (the lowest level of governmental area: kampong). The actor that also acts as Mananwir (head/leader) of Mnu, is proactively communicating every reforestation program to community members or country's agent. CA is strongly indicated at the time of emolument to every group, even inter-group trust and solidarity was gambled in sustaining the CA. In accordance with Selamat (2010), Suharjito (2002a) revealed that working relationship in a society was based on the connection of relatives, neighborhood or proximity of location. It was not a single relationship, but it was multiple (many stranded) relationship. The connection explains that inter-individual relationship is not merely based on economical calculation, however is also based on solidarity, social privilege and social status.

3 Primary actor

Actors associated with reforestation process can be categorized as keret member, government and NGO. In Biak community, mananwir holds important role (Mansoben 2003; 2007). Mananwir is a leader that retains important role in facilitating the occurrence of CA. Sumarti (1999) reported that collective action in rural society occurred when leader is capable of guiding the group norms in accordance with the interest of individual in the group. Amongst actors, it is the mananwir of mnu who retains important role to develop through kerets or mnu planting movement. The capability of mnu mananwir to mobilize other keret is influenced by its position as the agent of the country. Meanwhile, movement advocated by other actors, tends to reside in each keret (see summary in Table 4).

Referring to traditional leadership type, how the power of leadership acquired in Biak can be classified into leadership due to ascribed such as mananwir mnu, manseren mnu (land owner), and through achievement such as mambri (heroic character/warlord), korano (accomplished leader), manibob (possessing network in trading system), and konor (religious movement leader). Meanwhile leadership shown by traditional personage is mansabye (attempting to solve people's problems), mansernanem (smart and capable of recognizing new opportunities), mansowawa: (capable of carrying out/imitating procedure/ strategy of others), mamfanai (capable of and even clever to recognize opportunities) and this nature or characters are sometimes not mutually exclusive.

\section{Implication to reforestation}

1 Planting pattern and commodity

Planting pattern in reforestation is varied, such as line planting required by the government and random planting. Planting composition variation tended to be agroforestry and non-agroforestry. From the perspective of small scale traditional tree planting (in Indonesia), Snelder and Lasco (2008) indicated several tree planting models such as village forest, village forest garden and homegardens (Suharjito 2002b). Meanwhile, Alavalapati et al. (2004) classified agroforestry in tropical area as shown in Table 5. Reforestation in Biak can be classified into (i) agroforestry that includes multiple cropping and homegarden applied in marires area and (ii) monoculture and msen planting applied in yafdas land (Figure 2). Species composition established from the CA can be seen in Table 6 .

2 Innovation and technological transfer

It was found that the innovation capability of actor in Biak society can be classified into groups: first group carrying out planting in land in accordance with the established guidance of the government, and the second group trying to establish nursery and self-developed planting technique that sometimes was based on trial and error. Actor of the second group retains initial initiative to utilize the existing land for long-term planting activities. Apart from the trial of combining between its preferred species and agriculture/plantation species, actor carried

Table 5 Agroforestry practices in tropical areas

\begin{tabular}{ll}
\hline Agroforestry practices & Description \\
\hline Taungya (multiple cropping) & Agricultural plants planted in between and in the early stage of tree planting \\
Homegarden & Varied combination between trees and plants in the yards/gardens, there can exist livestock \\
Improved fallow & $\begin{array}{l}\text { Dominated by fast growing species with the purpose of enhancing the fertility of the soil as } \\
\text { well as for producing economic product }\end{array}$ \\
Multipurpose trees & $\begin{array}{l}\text { Fruit trees or others planted randomly or systematically to produce fruits, fire wood, } \\
\text { livestock food, wood and others }\end{array}$ \\
Combination between trees and other & Multi layer plants (plantation and forestry) \\
plants & Combination of trees and livestock business \\
Silvopasture &
\end{tabular}

Source: Alavalapati 2004 (modified) 


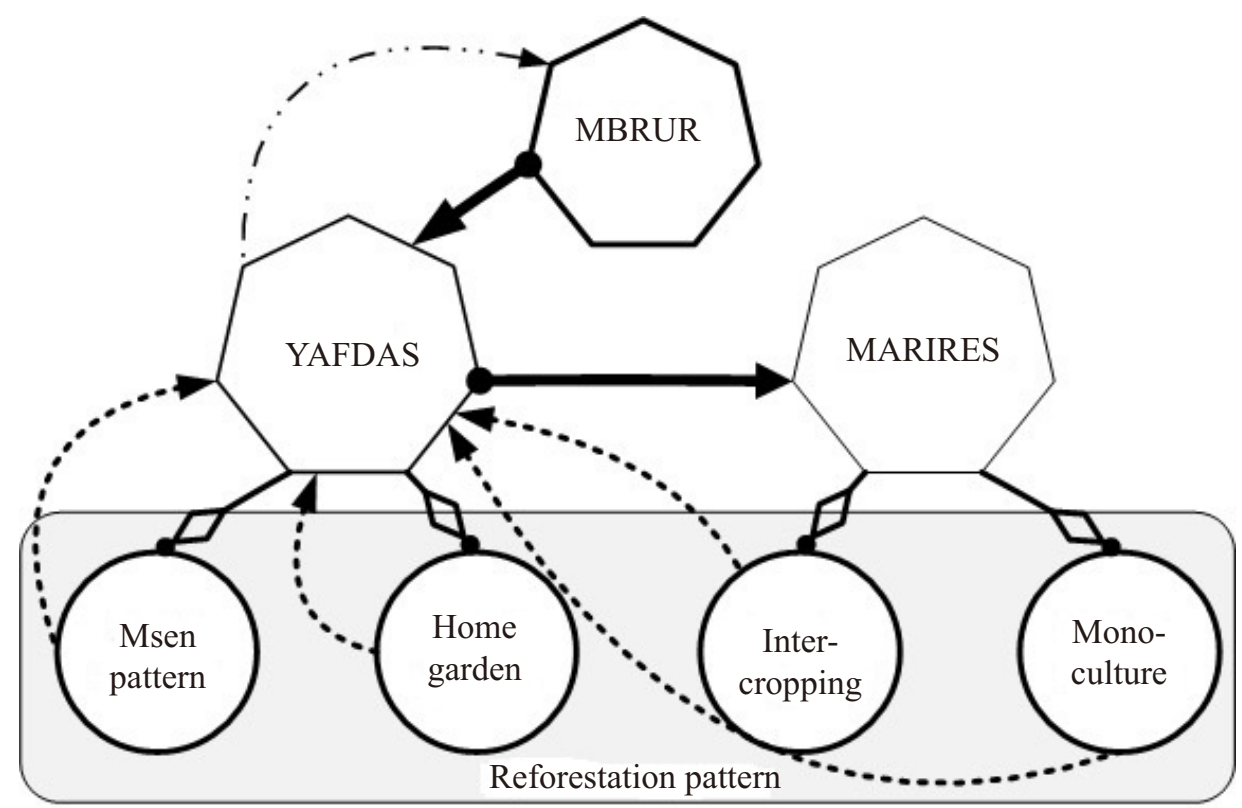

Figure 2 Landscape and reforestation pattern dynamic. Planting pattern $(\bigcirc)$, agrarian pattern $(\square)$, land shape change $(\bullet \rightarrow)$, shaped land tendency $(\rightarrow)$, land shape probably shaped (long-term) $(-\cdot \rightarrow)$, planting pattern existing in the agrarian pattern $(-\infty)$.

Table 6 Pattern of reforestation and commodity

\begin{tabular}{|c|c|c|}
\hline Reforestation pattern & Major commodities & $\begin{array}{l}\text { Location description/additional } \\
\text { commodities }\end{array}$ \\
\hline Planting in $m s e n$ & Agarwood (Aquilaria filaria) & $\begin{array}{l}\text { Yafdas; stand maintenance/other } \\
\text { species composition }\end{array}$ \\
\hline Home garden & $\begin{array}{l}\text { Agarwood (Aquilaria filaria), teak (Tectona grandis), melinjo } \\
\text { (Gnetum gnemon), jack fruit (Arthocarpus champeden), } \\
\text { mahkota dewa (Phaleria papuana) }\end{array}$ & $\begin{array}{l}\text { Yafdas; in combination with palm, } \\
\text { beetle leave, pineapple }\end{array}$ \\
\hline Multiple cropping & $\begin{array}{l}\text { Bintangur (Callophyllum inophyllum), merbau (Intsia bijuga), } \\
\text { matoa (Pometia pinnata), nyatoh (Palaquium sp.) }\end{array}$ & Marires; crops \\
\hline Monoculture & $\begin{array}{l}\text { Bintangur (Callophyllum inophyllum), merbau (Intsia bijuga), } \\
\text { matoa (Pometia pinnata), nyatoh ( Palaquium sp.),teak } \\
\text { (Tectona grandis), agathis (Agathis labilalderi), trembesi } \\
\text { (Samanea saman) }\end{array}$ & $\begin{array}{l}\text { Marires; plantation was left after } \\
\text { weeding }\end{array}$ \\
\hline
\end{tabular}

out agarwood planting in secondary forests called $m s e n$ (rocky forest), as well.

Actor even has developed germination technique of some seeds including the seed of agarwood. Direct planting method and germination technique with no growth hormone used were called an innovation. This innovation technique influenced the chance of the development survival of agarwood planting in msen and the availability of agarwood seedling for the recent planting area. Innovation dimension is important for CA in the area of indigenous society when actor is prepared to share or transfer innovation technology to other citizens.

By relating CA typology to the level of reforestation creativity and the established reforestation scale, then every typology can be placed in the quadrant at Figure 3. The effect of CA on reforestation can be thought as transformation result. Relationship based on reforestation impact on community agent (small group to cross through groups), and complexity/creativity of the established reforestation (reforestation relying on the government standard procedures/no innovation up to the tendency to be innovative or collaborative with more government empowerment programs).

Based on the explanation above, communal-based collective action that can be strengthen is as follow:

1 Collective action generated by the members of the community and supported by external power. The initiative that the community already possess has proved that this group is capable of developing the technique and to make innovation on the existing fields. Msen fields 
can be empowered for reforestation purpose. Reforestation is carried out by applying high value types, allowing the existence of other types of wood on the same tracks. In this group, the country can help strengthen the creativity possessed by the group.

2 Collective action generated by the prominent kampong figure authorized by the government. With the legitimacy possessed as the leader of kampong (mananwir $\mathrm{mmu}$ ), the prominent figure in the group will be capable of socializing activities/projects of planting better to the community. On the other hand, the relatively new information related to the country program can reach the community faster. The prominent figures are effective agents in communication between the community and the government.

3 Collective action generated by informal prominent figure (genealogical/kinship-based indigenous figure). The role of the indigenous as the gate-keeper holds strong indigenous legitimacy. The reforestation generated by the indigenous figure will be effective when it is related to the areas having certain history and keret identity existence of the indigenous figure.

Reforestation as part of CA only exists in yaflyafdas and marires/mamiai areas. There is no evidence that planting activity has been carried out in the areas of mbrur (Roembiak 2002).

In order to strengthen CA in Biak, the Uphoff (2000) theory on social capital can be used to explain how CA is constructive for stake holders mutually benefit collective action (MBCA). MBCA is promoted through the function of structural element of social capital (SC) such as:

1 actors role \& existing rule/norm in decision-making process, resources management and mobilization, communication and coordination, and conflict resolution; and

2 social and networking relationship that facilitate mutual and exchange practices.

In the cognitive element of $\mathrm{SC}$, trust and reciprocity elements need to be established and sustained due to its being crucial for the existence of stakeholder's relationship. Thus, solidarity develops due to the sense of loyalty and collectiveness, even beyond the limit of lineage. Uphoff (2000) emphasized that in order to take action, it is important to keep and develop an increasingly significant collaboration, and provide a considerable effect to the generosity of actors, or in the activity of reforestation interpreted as activity not merely rational oriented, but as activity to save environment and the identity and existence of keret in Biak and for the next generation sustainability. Mananwir of keret or mananwir of mnu as a leader holds a strategic role to ascertain the functioning of SC concepts in local institution existed in Biak. Besides that, country's agent stands facing the challenge of accomplishing substantial SC for the existence of reforestation in the land of indigenous community, and are able to proactively carrying out empowerment programs.

Based on leadership concepts found in Biak, it seems that people in Biak expect an effective leader (who is brave, patriotic, capable of mobilizing denizens or group to achieve collective goals), and he is also liked due to his capability of understanding every character of his group members. This kind of leadership was called by Haslam et al. (2011) Effective Leadership and Good Leadership. Effective leadership does not always appear as good leadership for the denizen.

...I saw it myself that as long as the group leader is a good man, they (denizens) are pleased, because all share the profit (sharing benefit). It depends on honesty and leadership...just as the Leader of Biak initiates the concept of Biak Mansonanem (highly minded person and act and all can eat)...do not understand that meaning... never just be irrational, politically used by authorities apparatus. To my understanding we cannot use the terminology arbitrarily...

...ayaisia...retains the element of humility...I am here for you (flexible) but ready...ready to sacrifice and so on

i.e....faiman...the one who unites is mansabye... (he always attempt to solve the problems of society).

Leadership is a process of the management of identity elements of a group to acquire certain goals (Marturano \& Gosling 2008). When leadership emphasizes the processes of social identity management, then it is categorized into psychology of leadership, and when it is centered at the content management of social identity such as the followings: who are we, what are our beliefs and value, then it can be called politics of leadership (Haslam et al. 2011). Awareness on identity as people of Biak that is presently establishing reforestation is the origin for the leader or development agents, to maintain social identity management for society development and empowerment objectives.

Finally, leadership concept in Biak that should be able to be developed in the aspect of relationship between group leader and its denizens, and that tends to involve the overall dimension of social identity management is faiman and mansabye. A faiman characterized leader will not present high expectations in the form of statements with "opened promises", but concentrate more on how to promptly but clearly comprehend the social identity of group he is managing. This can be done by faiman through comprehending problems phenomena faced by the group and immediately proceeded to solve these problems. Meanwhile, mansabye is a leader that always attempts to reconcile existing problems in society, therefore the unity and harmony in the Biak community can be sustained. Biak leaders are not limited to the mananwir group in the existing keret; however, it also includes all actors that work collaboratively to accomplish reforestation. It is believed that faiman and mansabye will lead the leaders of Biak to solidity in undertaking every initiative and program for the development of Biak, including reforestation.

\section{Conclusion}

Collective action process associated with reforestation in Papua, especially in Biak, retained its specific "story line" and was dynamic. Reforestation occurred due to the presence of initiator or pioneer that collaboratively utilized the land of society for long-term planting (wooden plants/forestry plants). In the course, society in 
keret group established reforestation through several CA typologies. Mutually beneficial $\mathrm{CA}$ can be referred to strengthen CA in the area of Biak indigenous community, e.g. through the concept of faiman and mansabye as an element retained by leaders, who are capable of managing the social identity of the existing group to promote reforestation.

\section{Suggestions}

In depth study is required on how to encourage the existing CA to strengthen the present reforestation with consideration of local agrarian structure. This study is expected to ascertain the findings of the present study.

\section{Acknowledgement}

The authors wish to sincerely acknowledge The Ministry of Forestry who funded the study. Special thanks also go to Enos Rumansara, Patrich Kawer, Andarias A Lameky, Agus Sumule, Marthen Kayoi, Godlief Kawer, indigenous personage of Biak (I S Rumaikeuw). Others are also worthy of our humble appreciation for very useful information, facilities and help.

\section{References}

Alavalapati JRR, Mercer DE, Montambault JR. 2004. Agroforestry systems and valuation methodologies: An overview. In: Alavalapati JRR, Mercer DE, editor. Valuing agroforestry systems. Netherlands: Kluwer Academic Publishers. pp1-8.

Ashmore RD, Deaux K, McLaughlin-Volpe T. 2004. An organizing framework for collective identity: articulation and significance of multidimensionality. Psychological Bulletin 130(1):80-114. http://dx.doi. org/10.1037/0033-2909.130.1.80.

Barth F. 1969. Introduction. In: Barth F, editor. Ethnic groups and boundaries. The social organization of culture difference. Boston: Little, Brown and Company. pp9-38.

Benford RD, Snow DA. 2000. Framing processes and social movements: An overview and assessment. Annual Review Sociology 26:611-639. http://dx.doi.org/10. 1146/annurev.soc.26.1.611.

Darusman D. 2002. Pembenahan Kehutanan Indonesia. Bogor: Institut Pertanian Bogor.

Dharmawan AH. 2007. Dinamika sosio-ekologi pedesaan. sodality: Jurnal Transdisiplin Sosiologi, Komunikasi, dan Ekologi Manusia. 1(1):1-40.

Eccles J. 2009. Who am I and what am I going to do with my life? Personal and collective identities as motivators of action. Educational psychologist 44(2):78-89 http://dx.doi.org/10.1080/00461520902832368.

Gamson AA. 1992. Social Psychology of Collective Action;
In: Morris AD, Mueller CM, editors. Frointers in Sosial Movement Theory. Yale: Yale University Press. pp5376.

Giddens A. 1984. The Constitution of Society: Outline of the Theory of Structuration. Cambridge: University of California Press.

Haslam SA, Reicher S, Platow M. 2011. The new psychology ofleadership: identity, influence, and power. New York: Psychology Press.

Hund SA, Benford RA. 2007. Collective Identity, Solidarity, and Commitment. In: Snow DA, Soule SA, Kriesi H, editor. The Blackwell Companion to Social Movements. Oxford: Blackwell Publishing Ltd. http://dx.doi.org/ 10.1002/9780470999103.ch19.

König T. 2000. The new age movement: genesis of a high volume, low impact identity [dissertation]. Italy: European University Institute.

Koentjaraningrat. 1990. Sejarah teori antropologi II. Jakarta: Universitas Indonesia Pres.

Le HD. 2012. More than just trees: Assessing reforestation success in tropical developing countries. Journal of Rural Studies 28(1):5-15. http://dx.doi.org/10.1016/j. jrurstud.2011.07.006.

Mansoben J. 2003. Sistem politik tradisional etnis Byak: Kajian tentang pemerintahan tradisional. Jurnal Antropologi Papua 1(3):1-31.

Mansoben J. 2007. The Socio-cultural Plurality of Papuan Society. In: Marshal AJ, Beehler BM, editors. The Ecology of Papua. Singapore: Periplus Editions. pp108-120.

Marturano A, Gosling J. 2008. Leadership-The Key Concepts. New York: Routledge.

Oliver PE, Johnston H. 2000. What a good idea-ideologies and frames in social movement research. Mobilization: An International Journal 4(1): 37-54.

Ojomo PA. 2011. Environmental ethics: An African understanding. The Journal of Pan African Studies 4(3):101-113.

Roembiak MDE. 2002. Status penggunaan dan pemilikan tanah dalam pengetahuan budaya dan hukum adat orang Byak. Jurnal Antropologi Papua 1(2):17-23.

Roggeband C, Klandermans B. 2007. Handbook of Social Movements Across Disciplines. In: Hernan V, Feagin JR, editors. Handbook of The Sociology of Racial and Etnic Relationship. New York: Springer. pp1-12.

Rudel TK. 2009. Tree farms: Driving forces and regional 
patterns in the global expansion of forest plantation. Land Use Policy 26(3):6. http://dx.doi.org/10.1016/j. landusepol.2008.08.003.

Rudel TK, Schneiderb L, Uriartec M. 2010. Forest transitions: An introduction. Land Use Policy. 27(2010):95-97. http://dx.doi.org/10.1016/j.land usepol.2009.09.021.

Sammut G. 2011. Civic Solidarity: the negotiation of identity in modern societies. Papers on Social Representations 20(4):1-24.

Sammut G, Gillespie A. 2011. Cultural encounters and social solidarity. Papers on Social Representations 20(1):1-7

Schlitz MM, Vieten C, Miller EM. 2010. Worldview transformation and the development of social consciousness. Journal of Consciousness Studies 17(78):18-36.

Selamat NH, Hashim IH, Gapor SA, Wahab JA. 2010. The Experience of collective action in capacity building programs: A case study of fishermen's wives group in Malaysia. European Journal of Social Sciences 16(4):490-501.

Snelder DJ, Lasco RD. 2008. Smallholder tree growing in South and Southeast Asia. In: Snelder DJ, Lasco RD, editors. Smallholder tree growing for rural development and environmental services lessons from Asia. New York: Springer. pp3-33.

Snow DA. 2004. Framing Processes, Ideology, and Discursive Fieds. In: Snow DA, Soule S, Kriesi H, editors. The Blackwell Companion to Social Movements.
Oxford: Blackwell. pp380-412

Suharjito D. 2002a. Kebun-talun: strategi adaptasi kultural dan ekologi masyarakat pertanian lahan kering di desa Buniwangi, Sukabumi, Jawa Barat [dissertation]. Jakarta: Pascasarjana Universitas Indonesia.

Suharjito D. 2002b. Choices of forest-garden crops: a study of peasant's decision making. Jurnal Manajemen Hutan Tropika 8(2): 47-56.

Suharjito D. 2008. Orientasi nilai dan gerakan masyarakat pro-konservasi di Indonesia. Media Konservasi 13(1):38-45.

Sumarti TMC. 1999. Persepsi kesejahteraan dan tindakan kolektif orang Jawa dalam kaitannya dengan gerakan masyarakat dalam pembangunan keluarga sejahtera di pedesaan [dissertation]. Bogor: Bogor Agricultural University.

Uphoff N. 2000. Understanding Social Capital: Learning from the Analysis and Experience of Participation. In: Dasgupta P, Serageldin I editors. Social Capital: A Multifaceted Perspective, Washington DC: World Bank.

Vicari S. 2010. Measuring collective action frames: A linguistic approach to frame analysis. Poetics 38(5):504-525. http://dx.doi.org/10.1016/j. poetic.2010.07.002.

Weber EP. 2000. A new vanguard for the environment: grassroots ecosystem management as a new environmental movement. Society and Natural Resources 12:237-259. http://dx.doi.org/10.1080/089419200279081. 